\title{
Cannabis consumption by female Psychology students: The influence of perceived stress, coping and consumption of drugs in their social environment
}

\author{
Consumo de cannabis en alumnas de Psicología: influencia del estrés \\ percibido, afrontamiento y consumo de drogas en su entorno
}

Recibido: noviembre 29 de 2010 | Revisado: enero 1 de 2011 | Aceptado: enero 17 de 2011

\author{
CRISTINA VARgas* \\ Humberto Manuel Trujillo** \\ Universidad de Granada, España
}

\begin{abstract}
A B S T R A C T
The consumption of cannabis has increased in the female population. The risk and protection factors associated with an increase or decrease in its consumption may differ as a function of gender, age and substance consumed. The objectives of the present study were to examine the relevance to cannabis consumption by female students of legal drugs consumed by the university students and family members, the consumption of legal and illicit drugs by friends, sociodemographic factors and, psychological variables (perceived stress and different coping strategies). Three questionnaires were administered to 465 female students studying for Psychology degrees. The prevalence of cannabis consumption was $36.3 \%$. The variables predicting its consumption were: a) consumption of illicit drugs and cocaine by friends; b) consumption of tobacco by the students and; c) emotion-oriented coping. Key words authors:

Cannabis, female students, coping strategies, perceived stress, drugs, peer group.

Key words plus:

Health psychology, consumption, psychological test.
\end{abstract}

\section{RESUMEN}

El consumo de cannabis se ha incrementando en la población femenina. Los factores de riesgo o de protección asociados con un incremento o disminución de su consumo, pueden diferir en función del género, edad o sustancia de consumo. Los objetivos del presente estudio fueron examinar la relevancia que tiene el consumo de drogas legales de las universitarias y familiares, el consumo de drogas legales e ilegales de amigos, factores sociodemográficos y variables psicológicas (estrés percibido y diferentes estrategias de afrontamiento) en el consumo de cannabis. Se administraron tres cuestionarios a 465 alumnas que cursaban la Licenciatura de Psicología. La prevalencia de consumo de cannabis fue de $36.3 \%$. Las variables que predecían su consumo fueron: a) consumo de drogas ilegales y cocaína en amigos; b) consumo de tabaco en las alumnas y c) afrontamiento orientado a la emoción.

Palabras clave autores:

Cannabis, universitarias, estrategias de afrontamiento, estrés percibido, drogas, grupo de iguales.

Palabras clave descriptores:

Psicología de la salud, consumo, pruebas psicológicas.

Docente-Investigador. Departamento de Me todologia de las Ciencias del Comportamien España.E-mail: cvargas@ugr.es

* Docente-Investigador. Departamento de Me todología de las Ciencias del Comportamiento. Facultad de Psicología. Universidad de G España.E-mail: humberto@ugr.es 
Cannabis is the most prevalent illicit drug in Europe. Adolescents and young adults (15 to 34 years) are the population groups that use cannabis most, particularly the age-band between 15 and $24(\mathrm{Ob}$ servatorio Europeo de las Drogas y las Toxicomanías [OEDT], 2007). In Spain, 26.6\% of the population between 15 and 64 have tried cannabis at some time, a significant increase, both in consumption and in the problems caused by cannabis, having occurred between 1994 and 2004/5 (Observatorio Español sobre Drogas [OED], 2007). The consumption of this substance is more extensive among men than women (OEDT, 2007). However, this disparity between the sexes regarding the consumption of cannabis has been decreasing in the last few years (Degenhardt et al., 2008). For example, in 2003, the prevalence of consuming it "at some time in my life" was $38.2 \%$ for men and $19.7 \%$ for women. In 2005, the percentage of consumption by men had decreased to $36.8 \%$ while for women it had increased to 20.1\% (OED, 2007).

For this reason, it is important to study the risk and protection factors associated with cannabis consumption by women as the prevalence of these variables could vary according to gender (Griffin, Scheier, Botvin, \& Diaz, 2000; Guxens, Nebot, \& Ariza, 2007). Likewise, these differences could be greater in young adults, since this group is characterised by its relative independence from social roles and normative expectations (Arnett, 2000). At this stage of life, risky conduct, including the consumption of drugs, is more common.

One risk factor associated with the consumption of cannabis is the consumption of legal drugs: amongst consumers of alcohol and tobacco the probability of consuming cannabis is increased (Agrawal et al., 2006; Agrawal \& Lynskey, 2009; Guxens, Nebot, Ariza, \& Ochoa, 2007; Kandel, 2003; Kandel \& Jessor, 2002). Other risk factors have been related to onset of cannabis use and consumption of cannabis such as approval of drugs or consumption of drugs in their social environment (family and peer group) (Agrawal, Lynskey, Bucholz, Madden, \& Heath, 2007; Cáceres, Salazar, Varela, \& Tovar, 2006; Ellickson, Tucker, Klein, \& Saner, 2007; Guxens, Nebot, Ariza, \& Ochoa,
2007; Kandel \& Davies, 1992; Yu \& Williford, 1992) and sociodemographic variables (Guxens, Nebot, Ariza, \& Ochoa, 2007).

Another possible risk variable is stress. People might, on a psychological level, be seeking through drug consumption a palliative escape from their condition, using mechanisms of negative reinforcement (Gordon, 2002). In several studies an association has been found between psychological stressors and the consumption of drugs: conflict in the work and/or marriage sphere (Lindenberg et al., 1999), belonging to an ethnic minority (FelixOrtiz \& Newcomb, 1999), psychological distress (Newcomb, Vargas-Carmona, \& Galaif, 1999), divorce (Agrawal \& Lynskey, 2009), family conflicts (Brook, Duan, Brook, \& Ning, 2007; McCuller, Sussman, Dent, \& Teran, 2001; Wu, Lu, Sterling, $\&$ Weisner, 2004), social anxiety (Buckner, Mallott, Schmidt, \& Taylor, 2006; Buckner, Schmidt, Bobadilla, \& Taylor, 2006), perceived stress and/or negative events in life (Anderson, Ramo, \& Brown, 2006; Mooney et al., 2008; Siqueira, Diab, Bodian, $\&$ Rolnitzky, 2000). However, the results of a direct relationship between stress and drug consumption are, at times, inconsistent (Furukawa et al., 1998).

This incoherence in the data could be due to the moderating effect of protection factors which, among others, affect coping. Wills and Hirky (1996) considered that coping strategies could decrease or increase the risk of drug consumption. Thus, adaptive coping (behavioural or cognitive) was considered to be a protective factor with regard to drug consumption in highly stressful situations and non-adaptive coping (avoidance or defencelessness coping) would increase the probability of consumption in the face of the impossibility of resolving the stressful situation (Anderson et al., 2006; Buckner, Schmidt et al., 2006; Davidson \& Ireland, 2009; Hussong \& Chassin, 2004; Siqueira et al., 2000; Wills, Sandy, Yaeger, Cleary, \& Shinar, 2001).

In other studies, a direct association has been found between coping strategies and drug consumption (Brook et al., 2007; Mooney et al., 2008; Siqueira, Diab, Bodian, \& Rolnitzky, 2001; Wu et al., 2004). Therefore, the question centres on whether coping is related to the consumption of 
drugs independently of the level of stress or whether coping processes are more relevant in people with high levels of stress.

The objectives of the present study were to examine the relevance to cannabis consumption by female students of legal drugs consumed by the university students and family members, the consumption of legal and illicit drugs by friends, sociodemographic factors and, psychological variables (perceived stress and different coping strategies, such as task-oriented, emotion-oriented and avoidance-oriented coping).

\section{Method}

\section{Participants}

Four hundred and sixty-five female students from the Faculty of Psychology (University of Granada) participated in the study. The average age of students was 20.83 ( $S D=3.093$ ). The participants agreed voluntarily to take part in the study.

\section{Measuring instruments}

CFR-P.ET Questionnaire (Martínez-González, Trujillo-Mendoza, \& Robles-Lozano, 2006). The questionnaire included 58 questions with open and closed format. Information was gathered on sociodemographic variables of the participants, habits of drug consumption amongst family members (only legal drugs), friends and those surveyed. Parameters of frequency, extent of use and age of initiation of consumption were registered.

Scale of Perceived Stress ([EEP], Cohen, Kamarck, \& Mermelstein, 1983) in the version adapted to Spanish (Trujillo \& González-Cabrera, 2007). The psychometric properties of this version are adequate and in agreement with the results obtained by Cohen et al. (1983). The degree to which life events were evaluated as stressful was assessed. The frequency of incidence of events perceived by the participants during the last month was described. The questionnaire consisted of 14 items with a response format of the Likert type (1, Never, and 6, Always).
The Coping Inventory for Stressful Situations (Endler \& Parker, 1990), in its version adapted to Spanish by Sánchez-Elvira, González and López (1996). The psychometric properties and factorial structure of this version are acceptable and in agreement with the results obtained by Endler and Parker (1990). This multi-dimensional inventory assessed habitual styles of coping with difficult, stressful or awkward situations. It consisted of 48 items with levels of response ranging between 1 and 6 (Likert-type). Three basic coping styles were evaluated: task-oriented, emotion-oriented and avoidance-oriented.

\section{Procedure}

A complete counterbalancing of the questionnaires was carried out to control the effects of order and transference. The questionnaires were administered in group situations in the classrooms.

Instructions for answering the questionnaires were given and participants were advised of the importance of not leaving any questions blank. Their anonymity was guaranteed. All students decided voluntarily to participate in the study. The administrator remained present while the tests were carried out.

\section{Statistical analysis}

The data of the students were analysed using descriptive techniques to estimate the prevalence of cannabis consumption.

Bivariable associations were found between the predictors (sociodemographic variables and consumption of legal drugs by family members, those surveyed and friends, in addition to illicit drugs by the latter) and the criterion (cannabis consumption). The statistical $t$-Student was used for age and a Pearson $\chi^{2}$ analysis for the categorical variables. All the statistically significant predictors were included in the multiple binary logistical regression analysis. In the selection of variables, we used the stepped method (the criterion of elimination was based on Wald's statistical probability). The first variable introduced into 
TABLE 1

Sociodemographic variables and cannabis consumption

\begin{tabular}{lccccc}
\hline & Do not consume & Consume & Chi-squared & gl & $p$ \\
\hline \multicolumn{1}{c}{ Stable relationship } & & & 4.288 & 1 & 0.038 \\
\hline Yes & $67.78(N=162)$ & $32.22(N=77)$ & & & \\
No & $58.45(N=128)$ & $41.55(N=91)$ & & & \\
\hline Living with & & & 9.617 & 1 & 0.002 \\
\hline Family & $70.89(N=151)$ & $29.11(N=62)$ & & & \\
Non-family & $56.91(N=140)$ & $43.09(N=106)$ & & & \\
\hline Parents living together & & & & & \\
\hline Yes & $65.44(N=267)$ & $34.56(N=141)$ & & \\
No & $47.92(N=23)$ & $52.08(N=25)$ & & & \\
\hline Father's Education & & & & \\
\hline Higher & $53.66(N=66)$ & $46.34(N=57)$ & & \\
Secondary & $69.85(N=95)$ & $30.15(N=41)$ & & \\
Primary & $65.92(N=118)$ & $34.08(N=61)$ & & \\
Uncompleted Primary & $50(N=9)$ & $50(N=9)$ & & \\
\hline
\end{tabular}

Fuente: elaboración propia.

the model was the one most closely correlated to the criterion variable, with the remaining variables being introduced one after another in the same way.

The bivariate correlations between the different questionnaires were obtained by means of a Pearson correlation analysis.

A multiple binary logistical regression analysis was carried out where each questionnaire was included separately and adjusted for the statistically significant predictor variables. Finally, a stepped multiple binary logistical regression analysis was used to examine the combined effect of all the questionnaires, adjusted for the predictor variables associated with the consumption of cannabis.

The SPSS 15.0.1 statistical package was used to analyse the data obtained.

\section{Results}

Of the 465 student who participated, $62.6 \%$ $(N=291)$ have not consumed cannabis, $28 \%$ $(N=130)$ have taken it sporadically and $8.4 \%$ $(N=39)$ regularly. Thus, $36.3 \%(N=169)$ of our sample are consumers and, every time they consume, $57 \%$ take one dose $(N=93)$ and $42 \%$ $(\mathrm{N}=70)$ two doses or more. The average age of ini- tiating cannabis consumption is $16.93(\mathrm{SD}=2.167)$.

The distribution of sociodemographic variables, as a function of the consumption of cannabis, is shown in Table 1 for those associations that are statistically significant. In female students with steady boyfriends, there was a higher percentage of non-consumers of cannabis than of consumers. Similar percentages were found in the group of non-consumers when the participants lived with family members, when their parents lived together or when the educational level of the father was primary or secondary education. The variables where no statistically significant differences were obtained were: age, work, socio-economic level and academic level of the mother.

Shown in Table 2 is the distribution of models of drug consumption in their social environment (family members and friends) and their own consumption of alcohol and tobacco as a function of cannabis consumption for those associations that are statistically significant. In general, it can be observed that the highest percentages of nonconsumption of different drugs by family members, friends and those surveyed are greater amongst students who do not consume cannabis. The variables where no statistically significant differences were found: consumption of alcohol by the father and by the mother. 
TABLE 2

Consumption of legal drugs by the students and drug consumption by those in their close environment associated with cannabis consumption

\begin{tabular}{|c|c|c|c|c|c|}
\hline & Do not consume & Consume & Chi-squared & $g l$ & $p$ \\
\hline Consume alcohol & & & 51.611 & 3 & 0.001 \\
\hline Do not drink & $96.15(N=50)$ & $3.85(N=2)$ & & & \\
\hline Twice a month & $73.87(N=82)$ & $26.13(N=29)$ & & & \\
\hline Weekends & $56.13(N=151)$ & $43.87(N=118)$ & & & \\
\hline Regularly & $25.93(N=7)$ & $74.07(\mathrm{~N}=20)$ & & & \\
\hline Consume tobacco & & & 77.092 & 2 & 0.001 \\
\hline Do not smoke & $84.69(\mathrm{~N}=177)$ & $15.31(N=32)$ & & & \\
\hline Weekends & $51.61(N=32)$ & $48.39(N=30)$ & & & \\
\hline Daily & $42.07(N=69)$ & $57.93(\mathrm{~N}=95)$ & & & \\
\hline $\begin{array}{l}\text { Consumption of tobacco by family } \\
\text { members }\end{array}$ & & & 15.977 & 6 & 0.014 \\
\hline None & $72.9(\mathrm{~N}=113)$ & $27.1(N=42)$ & & & \\
\hline Father & $66.67(\mathrm{~N}=52)$ & $33.33(N=26)$ & & & \\
\hline Mother & $64.71(N=33)$ & $35.29(N=18)$ & & & \\
\hline Siblings & $52.73(\mathrm{~N}=29)$ & $47.27(\mathrm{~N}=26)$ & & & \\
\hline Father and Mother & $56.67(\mathrm{~N}=17)$ & $43.33(N=13)$ & & & \\
\hline All & $43.75(N=7)$ & $56.25(N=9)$ & & & \\
\hline One parent and siblings & $52.7(\mathrm{~N}=39)$ & $47.3(N=35)$ & & & \\
\hline Consumption of alcohol by siblings & & & 11.787 & 2 & 0.003 \\
\hline Never & $73.23(\mathrm{~N}=93)$ & $26.77(N=34)$ & & & \\
\hline Occasionally & $59.7(\mathrm{~N}=157)$ & $40.3(N=106)$ & & & \\
\hline Frequently & $46.51(N=20)$ & $53.49(N=23)$ & & & \\
\hline Consumption of tobacco by friends & & & 33.389 & 4 & 0.001 \\
\hline None & $90(N=9)$ & $10(N=1)$ & & & \\
\hline Very few & $81.16(N=56)$ & $18.84(N=13)$ & & & \\
\hline Some & $70.33(N=128)$ & $29.67(N=54)$ & & & \\
\hline Nearly all & $49.47(N=93)$ & $50.53(N=95)$ & & & \\
\hline All & $45.45(N=5)$ & $54.55(N=6)$ & & & \\
\hline Consumption of alcohol by friends & & & 26.036 & 3 & 0.001 \\
\hline Never & $100(N=6)$ & $0(N=0)$ & & & \\
\hline Occasionally & $74.75(N=148)$ & $25.25(N=50)$ & & & \\
\hline Frequently & $53.57(N=135)$ & $46.43(N=117)$ & & & \\
\hline Daily & $33.33(N=1)$ & $66.67(N=2)$ & & & \\
\hline Consumption of illicit drugs by friends & & & 112.312 & 2 & 0.001 \\
\hline None & $91.56(N=141)$ & $8.44(N=13)$ & & & \\
\hline Some & $57.02(N=134)$ & $42.98(N=101)$ & & & \\
\hline Many & $19.4(N=13)$ & $80.6(N=54)$ & & & \\
\hline Consumption of cannabis by friends & & & 73.904 & 1 & 0.001 \\
\hline Yes & $48.35(N=132)$ & $51.65(N=141)$ & & & \\
\hline No & $89.81(N=141)$ & $10.19(N=16)$ & & & \\
\hline Consumption of cocaine by friends & & & 59.809 & 1 & 0.001 \\
\hline Yes & $22.06(N=15)$ & $77.94(N=53)$ & & & \\
\hline No & $71.27(N=258)$ & $28.73(N=104)$ & & & \\
\hline
\end{tabular}




\begin{tabular}{lccrcc}
\hline & Do not consume & Consume & Chi-squared & gl & $p$ \\
\hline Consumption of ecstasy by friends & & & 47.764 & 1 & 0.001 \\
\hline Yes & $31.4(\mathrm{~N}=27)$ & $68.6(\mathrm{~N}=59)$ & & & \\
No & $71.51(\mathrm{~N}=246)$ & $28.49(\mathrm{~N}=98)$ & & & \\
\hline Consumption of psychoactive drugs by & & & 9.091 & 1 & 0.003 \\
friends & & & & \\
\hline Yes & $26.67(\mathrm{~N}=4)$ & $73.33(\mathrm{~N}=11)$ & & \\
No & $64.82(\mathrm{~N}=269)$ & $35.18(\mathrm{~N}=146)$ & & \\
\hline
\end{tabular}

Fuente: elaboración propia.

The variables statistically associated with the criterion variable (see Tables 1 and 2) were included in a multiple logistical regression analysis. The results of the predictor variables that make up the model appear in Table 3. The analysis shows how students with some friends who consume illicit drugs run seven times more risk of consuming cannabis than those with no friends who consume illicit drugs. This risk increases for those students with many friends consuming illicit drugs (47.070 times more probable that they consume cannabis). The probability of consuming cannabis is higher when students consume tobacco at weekends or daily compared with those who do not consume tobacco (a risk of 6.445 and 6.985, respectively). Similarly, the risk of consuming cannabis is higher when participants have friends who consume cocaine compared with those whose friends do not consume this drug (3.098 times more probable that they consume cannabis).

Statistically significant bivariable correlations were found between the possible combinations of stress, task coping, emotional coping and avoidance coping, with the exception of the relationship between stress and avoidance coping (Table 4).

TABLE 3

Multiple binary logistic regression analysis for the variables predicting cannabis consumption

\begin{tabular}{|c|c|c|c|c|c|c|c|c|}
\hline \multirow{2}{*}{ Variables } & \multirow[t]{2}{*}{$\beta$} & \multirow[t]{2}{*}{ E.T. } & \multirow[t]{2}{*}{ Wald } & \multirow[t]{2}{*}{$g l$} & \multirow[t]{2}{*}{$p$} & \multirow[t]{2}{*}{ OR } & \multicolumn{2}{|c|}{ Confidence Interval 95\% } \\
\hline & & & & & & & Lower bound & Upper bound \\
\hline \multicolumn{9}{|c|}{ Consumption of illicit drugs by friends } \\
\hline None (reference) & & & 54.508 & 2 & 0.001 & & & \\
\hline Some & 1.944 & 0.381 & 25.972 & 1 & 0.001 & 6.984 & 3.307 & 14.749 \\
\hline Many & 3.852 & 0.525 & 53.895 & 1 & 0.001 & 47.070 & 16.833 & 131.622 \\
\hline \multicolumn{9}{|l|}{ Tobacco } \\
\hline Do not smoke (reference) & & & 41.241 & 2 & 0.001 & & & \\
\hline Weekends & 1.863 & 0.396 & 22.100 & 1 & 0.001 & 6.445 & 2.964 & 14.015 \\
\hline Daily & 1.944 & 0.318 & 37.396 & 1 & 0.001 & 6.985 & 3.746 & 13.022 \\
\hline \multicolumn{9}{|c|}{ Consumption of cocaine by friends } \\
\hline $\begin{array}{l}\text { Yes } \\
\text { No (reference) }\end{array}$ & 1.131 & 0.383 & 8.706 & 1 & 0.003 & 3.098 & 1.462 & 6.564 \\
\hline
\end{tabular}

Fuente: elaboración propia. 
TABLE 4

Correlations between perceived stress and coping strategies

\begin{tabular}{lcccc}
\hline & Stress & Task coping & Emotional Coping & Avoidance coping \\
\hline Stress & 1 & $-0.331^{* *}$ & $0.588^{* *}$ & 0.021 \\
Task coping & & 1 & $-0.176^{* *}$ & $0.172^{* * *}$ \\
Emotional coping & & & 1 & $0.136^{* *}$ \\
\hline
\end{tabular}

$* * p<0.01$ (bilateral)

Fuente: elaboración propia.

A marginally significant association $(p=0.053)$ is obtained between emotion-oriented coping and the consumption of cannabis in a binary logistic regression analysis: the decrease of one unit in emotional coping increases the risk of cannabis consumption (a risk of 1.372). Task and avoidance coping strategies, like perceived stress, do not predict the criterion variable.

A multiple binary logistic regression analysis was used to evaluate the effects of the different scales jointly. Perceived stress, avoidance-oriented and task-oriented coping were not included in the model. The final model consisted of the variables: consumption of illicit drugs by friends, consumption of cocaine by friends, consumption of tobacco by the students themselves and emotion-oriented coping (Table 5).

TABLE 5

Model predicting consumption of cannabis

\section{Discussion}

The prevalence of cannabis consumption was $36.3 \%$. This percentage was higher than that obtained in previous studies in the group of women between 20 and 24 who have consumed cannabis at some time in their lives: $20.3 \%$ in $1995,26.2 \%$ in $1997,27.2 \%$ in 1999 and $32.8 \%$ in 2001 (OED, 2003). This tendency of rising cannabis consumption in women can also be understood in the context of its growing prevalence in the 15-64 population: $9.4 \%$ in $1995,14.8$ in $1997,13.3 \%$ in 1999 , $16.5 \%$ in $2001,19.7 \%$ in 2003 and $20.1 \%$ in 2005 (OED, 2007).

The increase in experimentation has been accompanied by an intensification in the consumption of cannabis. $23.7 \%$ of the students who have consumed cannabis have done so regularly, with $42.9 \%$ of the total number of consumers having

\begin{tabular}{|c|c|c|c|c|c|c|c|c|}
\hline \multirow[t]{2}{*}{ Variables } & \multirow[t]{2}{*}{$\beta$} & \multirow[t]{2}{*}{ E.T. } & \multirow[t]{2}{*}{ Wald } & \multirow[t]{2}{*}{$g l$} & \multirow[t]{2}{*}{$p$} & \multirow[t]{2}{*}{ OR } & \multicolumn{2}{|c|}{ Confidence Interval 95\% } \\
\hline & & & & & & & Lower bound & Upper bounc \\
\hline \multicolumn{9}{|c|}{ Consumption of illicit drugs by friends } \\
\hline None (reference) & & & 55.679 & 2 & 0.001 & & & \\
\hline Some & 1.933 & 0.383 & 25.48 & 1 & 0.001 & 6.91 & 3.262 & 14.638 \\
\hline Many & 3.99 & 0.537 & 55.113 & 1 & 0.001 & 54.056 & 18.852 & 155.001 \\
\hline \multicolumn{9}{|l|}{ Tobacco } \\
\hline Do not smoke (reference) & & & 42.761 & 2 & 0.001 & & & \\
\hline Weekends & 1.946 & 0.402 & 23.468 & 1 & 0.001 & 7.002 & 3.186 & 15.387 \\
\hline Daily & 2.003 & 0.322 & 38.625 & 1 & 0.001 & 7.413 & 3.941 & 13.944 \\
\hline \multicolumn{9}{|c|}{ Consumption of cocaine by friends } \\
\hline $\begin{array}{l}\text { Yes } \\
\text { No (reference) }\end{array}$ & 1.201 & 0.391 & 9.42 & 1 & 0.002 & 3.324 & 1.544 & 7.158 \\
\hline Emotional Coping & 0.316 & 0.164 & 3.734 & 1 & 0.053 & 0.729 & 0.529 & 1.005 \\
\hline
\end{tabular}

Fuente: elaboración propia. 
taken two or more doses at each intake. The age of initiation for cannabis consumption is relatively lower than that found in the Spanish population: a) 18.7 years of age for women in 2001, descending to 18.5 in 2005 ; b) 18.2 years for men both in 2001 and 2005. These results affirm that the disparities in cannabis consumption between men and women are diminishing, with high percentages obtained in both groups (OED, 2003, 2007).

The sociodemographic variables associated with a lower consumption of cannabis are having a steady partner, living with relatives and having parents who live together. Having a partner can favour the acquisition of social roles, and living with relatives in particular can be associated with greater conformity and a diminution of the motivation to use drugs (Yamaguchi \& Kandel, 1985). The family structure seems to play a significant role in the consumption of drugs and can act as a protective factor (Flewelling \& Bauman, 1990). Thus, it has been found that the presence of both parents in the family structure mediates in the relationship between peer pressure and drug consumption, moderating its effect (Farrell \& White, 1998). With regard to the variable father's education, the highest percentages of cannabis consumers were observed in the groups of students whose fathers had higher education or uncompleted primary education. Similar results have been found in other investigations (Brown, Schulenberg, Bachman, O’Malley, \& Johnston, 2001).

The consumption of tobacco and alcohol was found to be associated with cannabis consumption. These results are in agreement with the predictions given by Kandel and collaborators' model: the consumption of these legal drugs increases the probability of consuming cannabis (for example, Agrawal \& Lynskey, 2009; Guxens, Nebot, Ariza, \& Ochoa, 2007; Kandel, 2003; Kandel \& Jessor, 2002).

The social environment is of great importance in drug consumption, since drug-taking happens in a specific social context, bringing into play parameters that can facilitate their use. Thus, observing other people's behaviour with regard to the consumption of drugs will encourage their own consumption (Cáceres et al., 2006; Chas- sin, Pitts, \& Prost, 2002). In the current study, a greater relationship was found between consumption of cannabis and the consumption of illicit drugs by friends (cannabis, cocaine and ecstasy). The relationship with consumption of tobacco by family members and friends, consumption of alcohol by siblings and friends and psychoactive drugs in this last group is not as strong. The importance of the peer group in cannabis consumption by the students contrasts with the results obtained by Coffey, Lynskey, Wolfe, and Patton (2000). They observed that the influence of peers interacted with gender, this influence being found in the group of men consuming cannabis but not in the group of women. Other authors (Buckner, Mallott et al., 2006) found that socially anxious women are more vulnerable to the effect of peer influence than socially anxious men in cannabis consumption. Therefore, future research is necessary to determine whether peer influence in cannabis consumption is moderated by gender.

Of all the variables related to cannabis consumption, the predictors are consumption of tobacco by the students and of illicit drugs and cocaine by friends. These results confirm the importance of the peer group for the participants, specifically when their peers consume illicit drugs in general and cocaine in particular. This illicit drug is the second most prevalent, reaching the highest figures in the 15-34 age group (5.2\%). In relation to the consumption of tobacco at some time in their lives, the prevalence in women has increased $(60.4 \%$ in 1997 , $57.2 \%$ in $1999,60.7 \%$ in $2001,61.7 \%$ in 2003 and $63.3 \%$ in 2005), the differences between the sexes diminishing (Degenhardt et al., 2008; OED, 2007). In a study carried out by Mendoza, López-Pérez, and Sagrera (2007), significant gender differences were found in tobacco consumption: there was a strong upward tendency in the consumption of this legal drug in the group of women (at age 15-17). This worsening of tobacco consumption, in addition to the harm it causes to health, can increase the risk of cannabis consumption, as has been established in this study and others with samples of university students (for example, Font-Mayolas, Gras, \& Planes, 2006). 
A direct relationship between perceived stress and cannabis consumption was not obtained. The absence of an association may perhaps be due to the lack of sensitivity of the measurement used in our study, which would evaluate global perceived stress. This indicator constitutes one of the various components making up the process of stress, these components underlying the development of different measuring instruments (Herbert \& Cohen, 1996). So, investigations that examine the association between stress and substance consumption do not show unified criteria with respect to the measuring instruments since each of them would be centred on just one of the components of the stress process. Siqueira et al. (2001) employed in their study a measurement of negative life events and one of perceived stress (the one used in this study); they found that consumers of cannabis experienced more negative events although they did not report higher levels of perceived stress. On the other hand, these authors found no divergence between the two measures of stress as predictors of tobacco use (Siqueira et al., 2000). Perhaps certain components of stress are more sensitive to certain drugs.

Since the vulnerability factor (perceived stress) does not predict cannabis consumption, it has not been possible to assess whether the different coping strategies diminish or increase the risk of consumption in accord with Wills and Hirky's (1996) model.

A direct relationship was found between emotion-oriented coping and cannabis consumption: those students who used emotional coping strategies were less likely to consume cannabis. However, task and avoidance coping did not predict cannabis consumption. The relevance of a strategy directed at emotion could be due to the fact that this type of coping is more common in women (for example, Soderstrom, Dolbier, Leiferman, \& Steinhardt, 2000).

Thus, the final model predicting drug consumption consists of the consumption of illicit drugs and cocaine by friends, consumption of tobacco by the students and emotional coping.

The present study requires some comment about certain limitations: a) the present data were drawn from a female university sample and it may not nec- essarily be possible to generalize the results to men or to other samples; b) all participants in this study were female and this limits our ability to evaluate gender differences in outcomes; c), our study was a cross-sectional survey and therefore was limited in its ability to predict progression; d) our measure of global perceived stress may not be a sensitive measure for examining the association between stress and cannabis consumption. Future research should evaluate whether our outcomes vary across other populations (for example, men) or throughout lifetimes. Also stress should be measured with other measuring instruments.

In agreement with Becoña (2006), prevention should be focussed on setting in motion initiatives to halt the consumption of drugs and improve the variables associated with the initiation, progression and continuation of consumption of the various drugs. In relation to the results obtained on the variables of an individual, it would be pertinent to examine stress with other measuring instruments, increasing the repertoire of emotionally-oriented coping skills that allow us to control the pressure exercised by peers in drug consumption. There should also be intervention in the earlier chains related to cannabis consumption, especially tobacco. The consumption of this legal drug is growing in women and diminishing its consumption would reduce both its harmful effects on health and the probability of their going on to consume illicit drugs such as cannabis.

\section{References}

Agrawal, A., Grant, J. D., Waldron, M., Duncan, A. E., Scherrer, J. F., Lynskey, M. T., \& Heath, A. C. (2006). Risk for initiation of substance use as a function of age of onset of cigarette, alcohol and cannabis use: Findings in a Midwestern female twin cohort. Preventive Medicine, 43, 125-128. doi:10.1016/j.ypmed.2006.03.022

Agrawal, A., \& Lynskey, M. T. (2009). Correlates of later-onset cannabis use in the National Epidemiological Survey on Alcohol and Related Conditions (NESARC). Drug and Alcohol Dependence, 105, 71-75. doi:10.1016/j.drugalcdep.2009.06.017 
Agrawal, A., Lynskey, M. T., Bucholz, K. K., Madden, P. A. F., \& Heath, A. C. (2007). Correlates of cannabis initiation in a longitudinal sample of young women: The importance of peer influences. Preventive Medicine, 45, 31-34. doi:10.1016/j. ypmed.2007.04.012

Anderson, K. G., Ramo, D. E., \& Brown, S. A. (2006). Life stress, coping and comorbid youth: An examination of the stress-vulnerability model for substance relapse. Journal of Psychoactive Drugs, 38(3), 255-262.

Arnett, J. J. (2000). Emerging adulthood: A theory of development from the late teens through the twenties. American Psychologist, 55, 469-480. doi: 10.1037//0003-066X.55.5.469

Becoña, E. (2007). Bases psicológicas de la prevención del consumo de drogas. Papeles del Psicólogo, 28(1), 11-20.

Brook, J. S, Duan, T., Brook, D. W., \& Ning, Y. (2007). Pathways to nicotine dependence in African American and Puerto Rican young adults. The American Journal on Addictions, 16, 450-456. doi:10.1080/10550490701641132

Brown, T. N., Schulenberg, J., Bachman, J. G., O’Malley, P. M., \& Johnston, L. D. (2001). Are risk and protective factors for substance use consistent across historical time? National data from the high school classes of 1976 through 1997. Prevention Science, 2, 29-43. doi:10.1023/A:1010034912070

Buckner, J. D., Mallott, M. A., Schmidt, N. B., \& Taylor, J. (2006). Peer influence and gender differences in problematic cannabis use among individuals with social anxiety. Journal of Anxiety Disorders, 20, 1087-1102. doi:10.1016/j.janxdis.2006.03.002

Buckner, J. D., Schmidt, N. B., Bobadilla, L., \& Taylor, J. (2006). Social anxiety and problematic cannabis use: Evaluating the moderating role of stress reactivity and perceived coping. Behaviour Research and Therapy, 44, 1007-1015. doi:10.1016/j. brat.2005.08.002

Cáceres, D., Salazar, I., Varela, M., \& Tovar, J. (2006). Consumo de drogas en jóvenes universitarios y su relación de riesgo y protección con los factores psicosociales. Universitas Psychologica, 5(3), 501-510.

Chassin, L., Pitts, S. C., \& Prost, J. (2002). Binge drinking trajectories from adolescence to emerging adulthood in a high-risk sample: Predictors and substance abuse outcomes. Journal of Consulting and Clinical Psychology, 70, 67-78.

doi:10.1037//0022-006X.70.1.67

Coffey, C., Lynskey, M., Wolfe, R., \& Patton, G. C. (2000). Initiation and progression of cannabis use in a population-based Australian adolescent longitudinal study. Addiction, 95, 1679-1690. doi:10.1046/j.1360-0443.2000.951116798.x

Cohen, S., Kamarck, T., \& Mermelstein, R. (1983). A global measure of perceived stress. Journal of Health and Social Behavior, 24, 385-96.

Davidson, S., \& Ireland, C. A. (2009). Substance misuse: The relationship between attachment styles, personality traits and coping in drug and non-drug users. Drugs and Alcohol Today, 9, 22-27.

Degenhardt, L., Chiu, W.-T., Sampson, N., Kessler, R. C., Anthony, J. C., Angermeyer, M. Bruffaerts, R., ...Wells, J. E. (2008). Toward a global view of alcohol, tobacco, cannabis, and cocaine use: Findings from the WHO World Mental Health Surveys. PLoS Medicine, 5, 1053-1067. doi:10.1371/journal. pmed.0050141

Ellickson, P. L., Tucker, J. S., Klein, D. J., \& Saner, H. (2007). Antecedents and outcomes of marijuana use initiation during adolescence. Preventive Medicine, 39, 976-984. doi:10.1016/j.ypmed.2004.04.013

Endler, N. S., \& Parker, J. D. (1990). Multidimensional assessment of coping: A critical evaluation. Journal of Personality and Social Psychology, 58, 844-854. doi:10.1037/0022-3514.58.5.844

Farrell, A. D., \& White, K. S. (1998). Peer influences and drug use among urban adolescents: Family structure and parent-adolescent relationship as protective factors. Journal of Consulting and Clinical Psychology, 66, 248-258. doi: 10.1037/0022-006X.66.2.248

Felix-Ortiz, M., \& Newcomb, M. D. (1999). Vulnerability for drug use among Latino adolescents. Journal of Community Psychology, 27, 257-280. doi:10.1002/ (SICI)1520-6629(199905)27:3<257::AID JCOP2>3.0.CO;2-0

Flewelling, R. L., \& Bauman, K. E. (1990). Family structure as a predictor of initial substance use and sexual intercourse in early adolescence. Journal of Marriage and the Family, 52, 171-181. 
Font-Mayolas, S., Gras, M. E., \& Planes, M. (2006). Análisis del patrón de consumo de cannabis en estudiantes universitarios. Adicciones, 18, 337-344.

Furukawa, T., Harai, H., Hirai, T., Fujihara, S., Kitamura, T., \& Takahashi, K. (1998). Childhood parental loss and alcohol dependence among Japanese men: A case-control study. Group for Longitudinal Affective Disorders Study (GLADS). Acta Psychiatrica Scandinavica, 97, 403-407. doi:10.1111/j.1600-0447.1998.tb10022.x

Gordon, H. W. (2002). Early environmental stress and biological vulnerability to drug abuse. Psychoneuroendocrinology, 27, 115-126. doi:10.1016/S03064530(01)00039-7

Griffin, K. W., Scheier, L. M., Botvin, G. J., \& Diaz, T. (2000). Ethnic and gender differences in psychosocial risk, protection, and adolescent alcohol use. Prevention Science, 1, 199-212. doi:10.1023/A:1026599112279

Guxens, M., Nebot, M., \& Ariza, C. (2007). Age and sex differences in factors associated with the onset of cannabis use: A cohort study. Drug and Alcohol Dependence, 88, 234-243. doi:10.1016/j.drugalcdep.2006.10.018

Guxens, M., Nebot, M., Ariza, C., \& Ochoa, D. (2007). Factors associated with the onset of cannabis use: A systematic review of cohort studies. Gaceta Sanitaria, 21, 252-260.

Herbert, T. B., \& Cohen, S. (1996). Measurement issues in research on psychosocial stress. In H. B. Kaplan (Ed.), Psychosocial stress. Perspectives on structure, theory, life-course, and methods (pp. 295-332). San Diego, CA: Academic Press.

Hussong, A. M., \& Chassin, L. (2004). Stress and coping among children of alcoholic parents through the young adult transition. Development and Psychopathology, 16, 985-1006. doi:10.1017/S0954579404040106

Kandel, D. B. (2003). Does marijuana use cause the use of other drugs? The Journal of the American Medical Association, 289, 482-483.

Kandel, D. B., \& Davies, M. (1992). Progression to regular marijuana involvement: Phenomenology \& risk factors for near-daily use. In M. D. Glantz, \& R. W. Pickens (Eds.), Vulnerability to drug abuse (pp. 211-253). Washington, DC: American Psychological Association.
Kandel, D. B., \& Jessor, R. (2002). The Gateway Hypothesis revisited. In D. B. Kandel (Ed.), Stages and pathways of drug involvement: Examining the Gateway Hypothesis (pp. 365-372). New York, N. Y.: Cambridge University Press.

Lindenberg, C. S., Strickland, O., Solorzano, R., Galvis, C., Dreher, M., \& Darrow, V. C. (1999). Correlates of alcohol and drug use among low-income Hispanic immigrant childbearing women living in the USA. International Journal of Nursing Studies, 36, 3-11. doi:10.1016/S0020-7489(98)00046-7

Martínez-González, J. M., Trujillo-Mendoza, H. M., \& Robles-Lozano, L. (2006). Factores de riesgo, protección y representaciones sociales sobre el consumo de drogas: implicaciones para la prevención. Sevilla: Junta de Andalucía.

McCuller, W. J., Sussman, S., Dent, C. W., \& Teran, L. (2001). Concurrent prediction of drug use among high-risk youth. Addictive Behaviors, 26, 137-142. doi:10.1016/S0306-4603(00)00082-4

Mendoza, R., López-Pérez, P., \& Sagrera, M. R. (2007). Diferencias de género en la evolución del tabaquismo adolescente en España (1986-2002). Adicciones, 19, 273-288.

Mooney, J. L., Minor, K. I., Wells, J. B., Leukefeld, C., Oser, C. B., \& Tindall, M. S. (2008). The relationship of stress, impulsivity, and beliefs to drug use severity in a sample of women prison inmates. International Journal of Offender Therapy and Comparative Criminology, 52, 686-697. doi:10.1177/0306624X07309754

Newcomb, M. D., Vargas-Carmona, J., \& Galaif, E. R. (1999). Drug problems and psychological distress among a community sample of adults: Predictors, consequences, or confound? Journal of Community Psychology, 27, 405-429. doi:10.1002/(SICI)1520-6629(199907)27:4<405:: AID-JCOP4>3.0.CO;2-2

Observatorio Español sobre Drogas. (2003). Informe n ${ }^{\circ} 6$. Observatorio Español sobre Drogas. Madrid, Spain: Ministerio del Interior.

Observatorio Español sobre Drogas. (2007). Informe 2007 del Observatorio Español sobre Drogas. Situación y tendencias de los problemas de drogas en España. Madrid, Spain: Ministerio de Sanidad y Consumo. 
Observatorio Europeo de las Drogas y las Toxicomanías. (2007). Informe anual sobre el problema de la drogodependencia en Europea. Luxembourg, Luxembourg: OEDT.

Sánchez-Elvira, A., González, M. P., \& López, R. (1996, July). Coping strategies of healthy and unhealthy dimensions of personality. Communications presented in $8^{\text {th }}$ European Conference on Personality, Ghent, Belgium.

Siqueira, L., Diab, M., Bodian, C., \& Rolnitzky, L. (2000). Adolescents becoming smokers: The roles of stress and coping methods. Journal of Adolescent Health, 27, 399-408. doi:10.1016/S1054139X(00)00167-1

Siqueira, L., Diab, M., Bodian, C., \& Rolnitzky, L. (2001). The relationship of stress and coping methods to adolescent marijuana use. Substance Abuse, 22, 157-166. doi:10.1023/A:1011173512033

Soderstrom, M., Dolbier, C., Leiferman, J., \& Steinhardt, M. (2000). The relationship of hardiness, coping strategies, and perceived stress to symptoms of illness. Journal of Behavioral Medicine, 23, 311 328. doi:10.1023/A:1005514310142

Trujillo, H. M., \& González-Cabrera, J. M. (2007). Propiedades psicométricas de la versión española de la "Escala de estrés percibido" (EEP). Psicología Conductual, 15, 457-478.
Wills, T. A., \& Hirky, A. E. (1996). Coping and substance abuse: A theoretical model and review of the evidence. In M. Zeidner, \& N. S. Endler (Eds.), Handbook of coping: Theory, research, applications (pp. 279-302). New York, N. Y.: John Wiley \& Sons.

Wills, T. A., Sandy, J. M., Yaeger, A. M., Cleary, S. D., \& Shinar, O. (2001). Coping dimensions, life stress, and adolescent substance use: A latent growth analysis. Journal of Abnormal Psychology, 110, 309-323. doi:10.1037/0021-843X.110.2.309

Wu, N. S., Lu, Y., Sterling, S., \& Weisner, C. (2004). Family environment factors and substance abuse severity in an $\mathrm{HMO}$ adolescent treatment population. Clinical Pediatrics, 43, 323-333. doi:10.1177/000992280404300403

Yamaguchi, K., \& Kandel, D. B. (1985). On the resolution of role incompatibility: A life event history analysis of family roles and marijuana use. American Journal of Sociology, 90, 1284-1325. doi:10.1086/228211

Yu, J., \& Williford, W. R. (1992). The age of alcohol onset and alcohol, cigarette, and marijuana use patterns: An analysis of drug use progression of young adults in New York State. International Journal of the Addictions, 27, 1313-1323. doi:10.3109/10826089209047353 